\title{
Clinical And Radiological Significance of Sella Turcica: A Literature Review
}

\author{
Melek Tassoker, Sevgi Ozcan \\ Department of Oral and Maxillofacial Radiology, Necmettin Erbakan University, Konya, Turkey
}

\begin{abstract}
The radiological interpretation and significance of changes in the sella turcica are dependent on an knowledge of the normal anatomy and pathology of this structure. Clincians should recognize variations in the anatomical structures found on cephalometric films so as to exclude any pathological changes, even before these become clinically apparent. The pituitary gland occupies the sella turcica and it is considered to be a site for brain tumours. Sellas of unusual size, shape and/or with a poorly defined outline may indicate pituitary problems and may be associated with some types of craniofacial malformation and various syndromes.
\end{abstract}

Keywords: Sella turcica, morphology, variation

\section{Introduction}

In orthodontics, the sella turcica is a significant anatomical structure because the sella point, $\mathrm{S}$, one of the most commonly used landmarks in cephalometrics, is located at the centre of the sella turcica [1]. Since the introduction of cephalometric radiography by Broadbent in 1931 the centre of sella turcica has been used in many cephalometric analyses [2]. This point is relatively stable because the morphology of sella turcica does not change significantly after 12 years of age [3].

Sella turcica gets its name from Turkish language because of its similarity to the Turkish saddle [4]. On lateral radiographs the sella turcica or pituitary fossa is the radiodense saddle-shaped outline of the fossa extending between the anterior and posterior clinoid processes. In healthy individuals the surface area of the sella turcica varies from $18-115 \mathrm{~mm}^{2}$ in females and from 22-122 $\mathrm{mm}^{2}$ in males. The shape of sella turcica is usually oval, but round and flat types can also occur [2].

This review aims to expand our understanding of sellar area variations and related any pathological and syndromic conditions.

\section{Anatomy and Embryology}

The sphenoid bone is located between the frontal, temporal and occipital bones in the base of the skull. It has a central body, paired greater and lesser wings spreading laterally from it and two pterygoid processes, descending from the junctions of the body and greater wings. The body of sphenoid forms central part of middle cranial fossa [5]. The sella turcica is situated on the intracranial surface of the body of the sphenoid bone. The anterior border of the sella turcica is represented by the tuberculum sellae and the posterior border by the dorsum sellae. The pituitary gland is surrounded by the sella turcica, whereas two anterior and two posterior clinoid processes project over the pituitary fossa. The anterior clinoid processes are formed by the medial and anterior prolongations of the lesser wing of the sphenoid bone, and the posterior clinoid processes by the endings of the dorsum sellae [6].

The greater part of the sphenoid bone develops using the endochondral method of ossification. Until the seventh or eighth month of foetal life the body of the sphenoid consists of two parts: the presphenoid (in front of the tuberculum sellae) and the postsphenoid (comprising the sella turcica and dorsum sellae). The presphenoid cartilages will form the anterior body of the sphenoid bone. Portions of the presphenoid cartilage give rise to the cartilage, which forms the central portion of the anterior skull base. The postsphenoid cartilage encloses the pituitary gland and fuses to form the basisphenoid, from which the sella turcica and the posterior body of the sphenoid bone originate [7].

During embryological development, the sella turcica area is a key point for the migration of the neural crest cells to the frontonasal and maxillary developmental fields [6]. The pituitary fossa itself is situated within the body of the sphenoid bone and differentiates directly from the hypophyseal cartilage of the early chondrocranium. The hypophyseal cartilage is derived from cranial neural crest cells [8]. 


\section{Shape of sella turcica}

Variations in the shape of sella turcica have long been reported by many researchers [4,9-17]. The shape of sella turcica was classified in to circular, oval, and flattened or saucer-shaped and majority of the subjects had either a circular or oval shaped sella $[18,19]$.

Gorden and Bell [9] in 1922 examined radiographs of normal children in between 1 and 12 years of age and categorized sella turcica into three shapes, circular, oval, flat/saucer shaped. Circular or oval shaped sella turcica were observed in majority of subjects, and they arrived at a conclusion that not all cases could easily be put into such a broad three-way classification.

Axelsson et al. [20] categorized the shape of sella turcica into six main types: normal sella turcica, oblique anterior wall, double contoured sella, irregularity (notching) in the posterior part of the sella, pyramidal shape of the dorsum sellae, and sella turcica bridge (Figure 1). In his study, normal morphology was found in $71 \%$ of males and $65 \%$ of females.

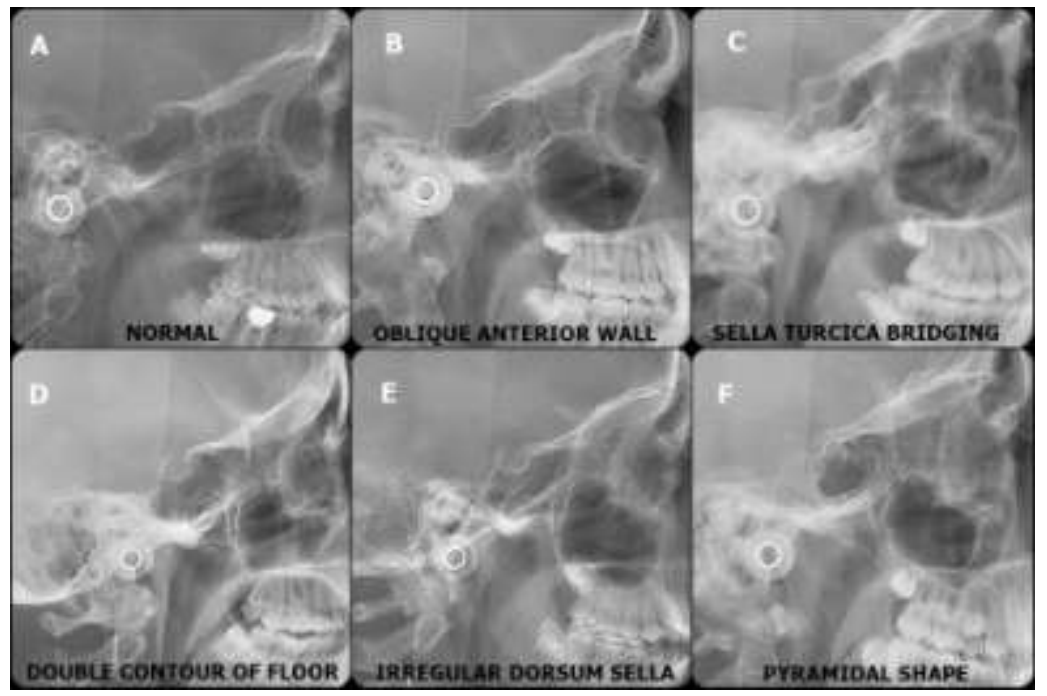

Figure 1. Different morphological variants of Sella Turcica seen on lateral cephalometric radiographs (a:normal, b:oblique anterior wall, c:sella turcica bridging, d:double contour of floor, e:irregular dorsum sella, f:pyramidal shape).

Alkofide [17] in 2007 stated that the normal shaped sella were seen almost in 67\% (2/3rd) of the subjects. Shah et al. [16] found that the variation in the shape of the sella was present in $34 \%$ of the subjects. Nagaraj et al. [4] pointed that morphological variations in shape were seen in $53,5 \%$ of study population.

The morphological variations of sella turcica with greater severity are more commonly seen in syndromic patients such as Down's syndrome, William's syndrome, Seckel syndrome, and AxenfeldRieger syndrome [21-24]. An altered sella turcica morphology can be present in patients with spina bifida [25]. Two cases with Rieger's syndrome were reported by Koshino et al. [26] the sellas in both cases were characterised by the 'J-shaped' sella turcica (Figure 2).

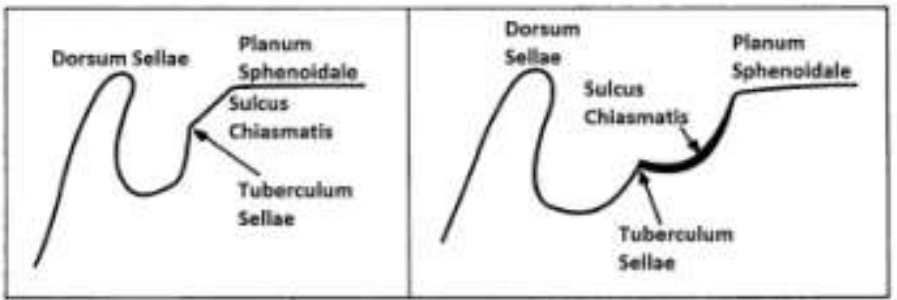

Figure 2. Schema of normal (left) and J-shaped (right) sella turcica

Alkofide [27] conducted a study to evaluate the morphological shapes of sella turcica in cleft lip and palate patients in 2008, according to the study contrary to individuals with clefts, in most noncleft subjects the morphology of the sella turcica appears to be normal. 
Sella turcica morphology has been studied in a group of children with lumbosacral myelomeningocele using profile skull radiographs. In all cases the anterior wall of the sella turcica differed from normal morphology [28].

Additional pathological conditions associated with abnormal development of the sella turcica and pituitary gland are holoprosencephaly, Meckel-Gruber syndrome, anencephaly, trisomy 18, chondrodystrophy, hydrocephalus, fragile $\mathrm{X}$ syndrome, Turner syndrome, Cri-du-Chat syndrome, Arnold Chiari syndrome, velocardiofacial syndrome, Kallmann syndrome [29].

\section{Sella turcica bridging}

A sella turcica bridge is the bony union that occasionally occurs between the anterior and posterior clinoid processes of the sphenoid bone [2]. The prevalence of a sella turcica bridging or calcification of the interclinoid ligaments was reported in the literature between 1,1\% [17]-17,6\% [30].

This osseous structure has been termed differently in the literature: interclinoid taenia [31], interclinoid bars [32,33], interclinoid osseous bridge [34], sella turcica bridge / bridging [1,30,32,35-37], sella bridge [38], roofing / bulging / calcification of the diaphragma sellae [12,30,36,37], calcified / ossified interclinoid ligament [31,33,40], and bridged sella [13,40].

Various possible causes of the formation of a sella turcica bridge can be predicted. First, it must be realized that the radiographic appearance of fusion may be due to the superimposition of structures and that there is not real bony fusion in all cases. Secondly, a sella turcica bridge could be a malformation from prenatal life. The entire cranial base is cartilage-performed from about the 5th foetal week [25]. Lang [40] described a sella turcica bridge in a newborn and in a 9-year-old child. It has been suggested that interclinoid ligament is laid down in cartilage at an early stage of development and then ossifies in very early childhood [31]. According to this theory, a sella turcica bridge should be considered a deveopmental anomaly [30]. Formation of the sellar bridges may result directly from the pattern of sphenoid development or can be dictated by the physiological activities of chemical compounds that are involved in embryogenesis and build up the bones. Ossification of the interclinoid ligament can be complete or partial [33].

Several endocrinological and neurological disorders associated with sella turcica bridging. Sellar bridges were demonstrated radiographically to a $25 \%$ extent in idiots, to $20 \%$ in criminals, to $15 \%$ in epileptics, and to $38 \%$ in other cases with mental disorders [5]. Higher prevalences of sella bridges have been reported in patients with severe craniofacial deformities and with increased mandibular and maxillary overjets [2] and with dental transpositions [37]. The type of malocclusion appears to play an important part in the prevalence of sella bridging [2]. Becktor et al. [25] and Jones et al. [35] analysed the frequency of a sella turcica bridge in patients with severe craniofacial deviations. They found a higher prevalence of a sella turcica bridge of $18.6 \%$ and $16.7 \%$, respectively, in patients who required combined surgical-orthodontic treatment. The higher incidence of sella turcica bridging was found in individuals with class III compared with class I and II malocclusions [1,2,41-43].

Altered sella turcica morphology or bridging of the sella turcica seems to be related to a symptom of a syndrome [1]. The occurrence of a sella turcica bridge has been described as a radiographic feature in basal cell carcinoma (Gorlin-Goltz) syndrome, Rieger syndrome, and other disorders and syndromes [44,45,24,26].

Furthermore, the knowledge of structural anomalies is essential for safety in surgical management; the variations in the clinoid processes and the detailed anatomy of the interclinoid ligament should be carefully studied by neurosurgeons. The anterior clinoidectomies (removal of anterior clinoid process) has been used by surgeons to gain access to the clinoid space for the successful management of aneurysms of the carotid-opthalmic artery and for tumors of the clinoid region [46]. The presence of an ossified ligament between the anterior and posterior clinoid processes may make intracranial surgical procedures such as removal of meningiomas from the tubercle of the sella and treatment of paraclinoid aneurysms even more difficult and risky. For this reason, descriptions of occurences of ossification of the interclinoid ligament continue to be important [47].

The interclinoid ligament bisects the wall of the cavernous sinus, dividing it into two triangles; carotid trigone anteromedially and occulomotor trigone posterolateral. Thus ossification of this ligament may influence such structures as the internal carotid artery or the occulomotor nerve [5].

\section{Size of sella turcica}

Data on the size of the sella turcica have been reported in the literature and typically range from 4 to $12 \mathrm{~mm}$ for the vertical and 5 to $16 \mathrm{~mm}$ for the antero-posterior dimension (Figure 3) $[35,48,49]$. The size of sella turcica was studied by Axelsson et al. [20] in a Norwegian sample longitudinally between the ages of 6 and 21 years. His study results demonstrated that the length was 
almost constant throughout the observation period whereas the depth and diameter increased with age [20]. Based on similar results, Nagaraj et al. [4] concluded that growth of the individual can be assessed by the size of the sella turcica at different age periods. Argyropoulou et al. [50] state that "It should be noted that an age-related increase of sella turcica size is expected because its contents, i.e. the hypophysis, have been shown to increase in size with age."

According to the results of the study conducted by Shah [16] no significant difference in size of the sella turcica could be found between males and females and no significant difference was found among sella size and skeletal type.

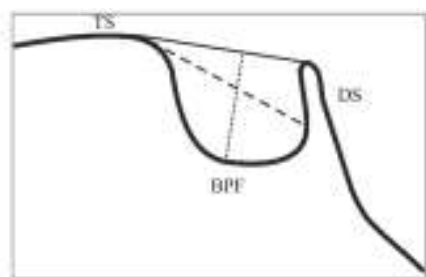

Figure 3. Reference lines for measuring sella size. TS: tuberculum sella, DS: dorsum sella, BPF: base of the pituitary fossa. Black line: length of the sella. Dashed line: diameter of sella. Dotted line: depth of sella.

A larger size may be an indication of pituitary tumor over producing hormones such as an adrenocorticotropic hormone, prolactin, growth hormone, thyroid stimulating hormone, antidiuretic hormone leading to Cushing's syndrome, amenorrhea, acromegaly. The enlarged sella turcica on a radiograph has been found to be associated with adenomas, mucocele, meningioma, primary hypothyroidism, prolactinoma, gigantism, acromegaly, empty sella syndrome, and Nelson syndrome [44,51,52]. In contrast, an abnormally small sella turcica seems to be rare and found in primary hypopituitarism and Sheehan's syndrome [52]. A small size may lead to decreased pituitary function causing symptoms such as short stature and retarded skeletal growth. Small sella turcica are notable in humans who either have an absent or a partial formed diaphragma sellae [16].

The largest percentage of intrasellar tumors is microadenomas (adenomas smaller than $10 \mathrm{~mm}$ in diameter) [19]. The most common causes of enlargement of sella turcica are the presence of intrasellar adenomas (e.g. prolactinoma) [53-55] and empty sella syndrome (intrasellar herniation of the suprasellar subarachnoid space) [53]. Other rare conditions like Rathke's cleft cysts and aneurysms can also cause enlargement [54]. Tumours such as craniopharyngioma and intrasellar aneurysm can be responsible for an enlargement of the sella turcica with bony destruction and invasion into the surrounding structures (56).

\section{Conclusion}

The normal anatomy and variations in the morphology and size of sella turcica on a lateral cephalometric radiograph should evaluate by clinicians for the purpose of analyze deviations that may reflect pathological situations. Knowledge of morphological variations is essential for understanding the etiology of some clinical symptoms and for safety in surgical management.

\section{References}

[1] Meyer-Marcotty P, Reuther T, Stellzig-Eisenhauer A. Bridging of the sella turcica in skeletal Class III subjects. Eur J Orthod 2010;32(2):148-53.

[2] Abdel-Kader HM. Sella turcica bridges in orthodontic and orthognathic surgery patients. A retrospective cephalometric study. Aust Orthod 2007;23(1):30-35.

[3] Norton LA, Melsen B. Functional appliances. In: Melsen B, editor. Current controversies in orthodontics. Chicago: Quintessence Publishing, 1991,p.103-30.

[4] Nagaraj T et al. The size and morphology of sella turcica: a lateral cephalometric study. JMRPS 2015;1(3):3-7.

[5] Kolagi S, Herur A, Patil G, Rairam GB. Complete sella turcica bridges prevalence and dimensions. J Anat Soc India 2011;60(1):2225.

[6] Kjaer I, Keeling JW, Fischer-Hansen B. The prenatal human cranium-normal and pathologic development. Munksgaard, Copenhagen, 1999.

[7] Lang J. Skull base and related structures. Atlas of clinical anatomy. Shattauer, Stutgart, New York, 1995.

[8] McBratney-Owen B, Iseki S, Bamforth SD, Olsen BR, Morriss-Kay GM. Development and tissue origins of the mammalian cranial base. Dev Biol 2008;322(1):121-132.

[9] Gordon MB, Bell AL. A roentgenographic study of the sella turcica in normal children. New York State J Med 1922;22:54-59.

[10] Camp JD. Normal and pathological anatomy of the sella turcica as revealed by roentgenograms. Am J Roentgenol 1924;12:143156.

[11] Teal JS. Radiology of the adult sella turcica. Bull Los Angeles Neurol Soc 1977;42(3-4):111-174. 
[12] Kantor ML, Norton LA. Normal radiographic anatomy and common anomalies seen in cephalometric films. Am J Orthod Dentofacial Orthop 1987;91(5):414-426.

[13] Tetradis S, Kantor ML. Prevalence of skeletal and dental anomalies and normal variants seen in cephalometric and other radiographs of orthodontic patients. Am J Orthod Dentofacial Orthop 1999;116(5):572-577.

[14] Ize-Iyamu NI. Sella turcica shape, linear dimensions, and cervical vertebrae staging in preorthodontic patients in Benin City, Nigeria. Sahel Med J 2014;17(4):151-158.

[15] Kucia A et al. Sella turcica anomalies on lateral cephalometric radiographs of Polish children. Dentomaxillofac Radiol 2014;43:2014065.

[16] Shah AM, Bashir U, Ilyas T. The shape and size of the sella turcica in skeletal class I, II, III in patients presenting at Islamic International Dental Hospital, Islamabad. Pak Oral Dent J 2011;31(1):104-10.

[17] Alkofide EA. The shape and size of the sella turcica in skeletal class I, class II and class III Saudi subjects. Eur J orthod 2007;29(5):457-463.

[18] Choi WJ, Hwang EH, Lee SE. The study of shape and size of normal sella turcica in cephalometric radiographs. Korean J Oral Maxillofac Radiol 2001;31(1):43-9.

[19] Andredaki M, Koumantanou A, Dorotheou D, Halazonetis DJ. A cephalometric morphometric study of the sella turcica. Eur J Orthod 2007;29(5):449-56.

[20] Axelsson S, Storhaug K, Kjaer I. Postnatal size and morphology of the sella turcica. Longitudinal cephalometric standards for Norwegians between 6 and 21 years of age. Eur J Orthod 2004;26(6):597-604.

[21] Axelsson S, Storhaug K, Kjaer I. Post-natal size and morphology of the sella turcica in Williams syndrome. Eur J Orthod 2004;26(6):613-21.

[22] Korayem M, AlKofide E. Size and shape of the sella turcica in subjects with Down syndrome. Orthod Craniofac Res 2015;18(1):4350.

[23] Kjaer I, Hansen N, Becktor KB, Birkebaek N, Balslev T. Craniofacial morphology, dentition, and skeletal maturity infour siblings with Seckel syndrome. Cleft Palate Craniofac J 2001;38(6):645-51.

[24] Meyer-Marcotty P, Weisschuh N, Dressler P, Hartmann J, Stellzig-Eisenhauer A. Morphology of the sella turcica in AxenfeldRieger syndrome with PITX2 mutation. J Oral Pathol Med 2008;37(8):504-10.

[25] Becktor J P, Einersen S, Kjær I. A sella turcica bridge in subjects with severe craniofacial deviations. Eur J Orthod 2000;22(1):6974.

[26] Koshino T, Konno T, Ohzeki T. Bone and joint manifestations in Rieger's syndrome: a report of a family. J Pediatr Orthop 1989;9(2):224-30.

[27] Alkofide EA. Sella turcica morphology and dimensions in cleft subjects. Cleft Palate Craniofac J 2008;45(6):647-53.

[28] Kjaer I, Wagner A, Madsen P, Blichfeldt S, Rasmussen K, Russell B. The sella turcica in children with lubosacral myelomeningocele. Eur J Orthod 1998;20(4): 443-448.

[29] Kjaer I. Sella turcica morphology and the pituitary gland-a new contribution to craniofacial diagnostics based on histology and neuroradiology. Eur J Orthod 2012;37(1):28-36.

[30] Leonardi R, Barbato E, Vichi M, Caltabiano M. A sella turcica bridge in subjects with dental anomalies. Eur J Orthod 2006;28(6):580-5.

[31] Ozdogmus O et al. Ossification of interclinoid ligament and its clinical significance. Neuroanatomy 2003;2(1):25-27.

[32] Archana R, Anita R, Jyoti C, Punita M, Rakesh D. Incidence of osseous interclinoid bars in Indian population. Surg Radiol Anat 2010;32(4):383-7.

[33] Skrzat J, Szewczyk R, Walocha J. The ossified interclinoid ligament. Folia Morphol 2006;65(3):242-5.

[34] Ertuk M, Kayalioglu G, Govsa F. Anatomy of the clinoidal region with special emphasis on the caroticoclinoid foramen and interclinoid osseous bridge in a recent Turkish population. Neurosurg Rev 2004;27(1):22-6.

[35] Jones RM, Faqir A, Millett DT, Moos KF, McHugh S. Bridging and dimensions of sella turcica in subjects treated by surgicalorthodontic means or orthodontics only. Angle Orthod 2005; 75(5):714-718.

[36] Leonardi R, Barbato R, Vichi M, Caltabiano M. Skeletal anomalies and normal variants in patients with palatally displaced canines. Angle Orthod 2009;79(4),727-32.

[37] Leonardi R, Farella M, Cobourne MT. An association between sella turcica bridging and dental transposition. Eur J Orthod 2011;33(4):461-5.

[38] Peker T et al. The incidence and types of sella and sphenopetrous bridges. Neurosurg Rev 2006;29(3):219-23.

[39] Cedeberg RA, Benso BW, Nunn M, English JD. Calcification of the interclinoid and petroclinoid ligaments of sella turcica: a radiographic study of the prevalence. Orthod Craniofac Res 2003; 6(4):227-32.

[40] Lang J. Structure and postnatal organization of heretofore uninvestigated and infrequent ossifications of the sella turcica region. Acta Anat 1977;99(2):121-39.

[41] Marsan G, Oztas E. Incidence of bridging and dimensions of sella turcica in Class I and Class III Turkish adult female patients. World J Orthod 2009;10(2):99-103.

[42] Sathyanarayana HP, Kailasam V, Chitharanjan AB. Sella turcica-its importance in orthodontics and craniofacial morphology. Dent Res J 2013;10(5):571-5.

[43] Valizadeh S, Shahbeig S, Mohseni S, Azimi F, Bakhshandeh H. Correlation of Shape and Size of Sella Turcica With the Type of Facial Skeletal Class in an Iranian Group. Iran J Radiol 2015;12(3):e16059.

[44] McLachlan MS, Wright AD, Doyle FH. Plain film and tomographic assessment of the pituitary fossa in 140 acromegalic patients. Br J Radiol 1970;43(510):360-369.

[45] Gorlin RJ, Pinborg JJ, Cohen MM. Syndromes of the head and neck, $2^{\text {nd }}$ Ed., McGraw-Hill, New York, 1976, p. 649-651.

[46] Perez IE, Chavez AK, Ponce D. Frequency of sella turcica bridge and clinoid enlargement in lateral cephalometric plain film radiography from Peruvians. Int J Morphol 2013;31(2):373-77.

[47] Aragao JA, Fontes LM, Aragao JMR, Reis FP. Ossification of interclinoid ligaments and their clinical importance. Int J Anat Var 2013;6:201-202.

[48] Silverman FN. Roentgen standards for size of the pituitary fossa from infancy through adolescence. Am J Roentgenol 1957;78:451460 .

[49] Chilton LA, Dorst JP, Garn SM. The volume of the sella turcica in children: new standards. AJR Am Roentgenol 1983;140(4):797801.

[50] Argyropoulou M, Perignon F, Brunelle F, Brauner R, Rappaport R. Height of normal pituitary gland as a function of age evaluated by magnetic resonance imaging in children. Pediatric Radiology 1991;21(4):247-249. 
[51] Friedland B, Meazzini C. Incidental finding of an enlarged sella turcica on a lateral cephalogram. Am J Orthod Dentofac Orthop 1996;110(5):508-512.

[52] Pribram HW, du Boulay GH. Sella turcica. In: Newton TH, Potts GP, editors. Radiology of skull and brain. St Louis, 1971, pp. 357-390.

[53] Weisberg LA, Zimmerman EA, Frantz AG. Diagnosis and evaluation of patients with an enlarged sella turcica. Am J Med 1976;61(5):590-6.

[54] Swallow CE, Osborn AG. Imaging of sella and parasellar disease. Semin Ultrasound CT MR 1998;19:257-71.

[55] Dostalova S, Sonka K, Smahel Z, Weiss V, Marek J. Cephalometric assessment of cranial abnormalities in patients with acromegaly. J Craniomaxillofac Surg 2003;31(2):80-7.

[56] Younghusband OZ, Horrax G, Hurxthal LM. Chromophobe pituitary tumors. J Clin Endocrinol Metab 1952;12(6):611-616. 